\title{
EXAMINING DUAL ACADEMIC CREDIT AND THE LOCATION OF INSTRUCTION AS A PREDICTOR OF 12TH GRADE NAEP READING SCORES
}

\author{
Rebekah Redmer ${ }^{1}$, Mingyuan Zhang ${ }^{*}{ }^{\star}$ \\ ${ }^{1,{ }^{*} 2}$ College of Education and Human Services, Central Michigan University, USA
}

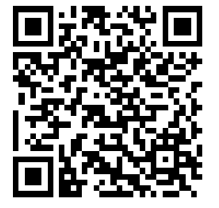

DOI: https://doi.org/10.29121/granthaalayah.v8.i11.2020.2404

Article Type: Research Article

Article Citation: Rebekah Redmer, and Mingyuan Zhang. (2020). EXAMINING DUAL ACADEMIC CREDIT AND THE LOCATION OF INSTRUCTION AS A PREDICTOR OF 12TH GRADE NAEP READING SCORES. International Journal of Research -GRANTHAALAYAH, 8(11), 296-310. https://doi.org/10.29121/granthaa layah.v8.i11.2020.2404

Received Date: 07 November 2020

Accepted Date: 30 November 2020

Keywords:

NAEP

12th-Grade

Dual Enrollment

ELA

Graduation Requirements

Secondary Education

\section{ABSTRACT}

This study explored 12th grade reading scores on the 2015 National Assessment of Educational Progress (NAEP) and how they relate to enrollment in dual credit college courses and the location in which they were taught. To gain a better understanding of dual credit attainment through various instructional delivery methods and the prediction of 12 th grade reading scores, data was mined from the 2015 NAEP and presented in this descriptive research study. The findings of this study include for 12th grades students: (1) Students who earned ELA dual college credit delivered at their high school campus did not result in higher NAEP reading scores. (2) Students who earned ELA dual college credit delivered at a postsecondary campus did not result in higher NAEP reading scores. (3) Students who earned ELA dual college credit delivered through distance learning had higher NAEP reading scores when $11-25 \%$ of the 12 th grade students enrolled. These findings make evident the high school campus or postsecondary campus dual credit courses for 12 th grade students did not have an impact or can be used as a predictor on the NAEP reading test. The dual credit distance learning did have a positive impact on the 12th grade NAEP reading scores, specifically if a smaller percentage of students at the school enrolled, identifying that increasing access to dual credit may not always translate to increased college readiness and rigor.

\section{INTRODUCTION}

Secondary education has evolved over the years, providing students with innovative opportunities that extend beyond the traditional scheduled pathway. At the state level, public high schools are provided curriculum standards, along with a course completion overview for graduation requirements that leads to a state-endorsed diploma. One growing option found within that pathway includes the selection of dual enrollment as part of the student's schedule each term; these courses are offered at the college level and allow high school students the ability to take them simultaneously, earning both high school and college credit (Zuidema and Eams, 2014). Even with the concept of dual enrollment existing for over 100 years (Zuidema and Earns, 2014), the increased interest in dual enrollment has mirrored both the accessibility and affordability in the past few decades that comes with multiple modes of dual enrollment delivery, and tuition support through state funding. As an example of this growth, during the 2010-2011 school year, $82 \%$ of U.S. high schools reported that students were enrolled in dual credit courses (Thomas, Marken,

(C) 2020 The Author(s). This is an open access article distributed under the terms of the Creative Commons Attribution License, which permits unrestricted use, distribution, and reproduction in any medium, provided the original author and source are credited. 
Gray and Lewis, 2016). With this increased attention to dual enrollment courses has come added financial allocation of school aid. In the State of Michigan over 120 million US dollars in dual enrollment tuition has been paid by the state during the 2015-2016, 2016-2017, and 2017-2018 school years (CEPI Database).

Exploring the various academic opportunities for secondary students, dual enrollment is a promising practice that aligns with frameworks relating to state-level career pathways and can be identified as either academic or career and technical education (CTE) in nature (Phelps and Chan, 2016). Focusing on the academic graduation requirements and pathways, there is an array of high school dual credit programs and research is needed to fully develop and understand the benefits and relationship to overall postsecondary preparedness, specifically college readiness. Additionally, barriers need to be addressed in order to increase accessibility to higher education, this includes not only the financial barriers that exist through tuition, textbook, and enrollment fees, but also transportation barriers for secondary students (Roach, Gamez Vargas and David, 2015), providing options for dual enrollment through course selections that include physical attendance on the college campus, on the high school campus, and through distance or online learning.

There is a deficiency in the lack of research as it relates to dual enrollment course completion and the location or mode (college campus, high school campus, or distance learning) in which student academic achievement can be measured. There are other modalities for postsecondary or college level credit attainment via courses accredited and offered by local high schools through College Board - Advanced Placement, International Baccalaureate, Project Lead The Way, and other articulation agreements established through partnerships. Dual enrollment in many states provides opportunity for direct transfer credit, relying less on the outcome of a single exam for the college credit, and more on the overall grade in the course and the postsecondary transcript that is created. With such a surge in dual enrollment, greater participation has yielded variability in eligibility requirements, opening up dual enrolment pathways to students with moderate levels of ability or achievement, not just those students who exhibit high ability and achievement (Howley, Howley, Howley and Duncan, 2013).

The intent of this study is to explore the impact on 12th grade reading scores on the 2015 National Assessment of Educational Progress (NAEP) and how they relate to enrollment in English dual credit college courses and the location in which they were taught.To further explore this relationship, this study focused on the following research questions:

1) Examine the impact on NAEP composite reading scores of students who enrolled in an English/language arts academic course for dual credit taught on a high school campus.

2) Examine the impact on NAEP composite reading scores of students who enrolled in an English/language arts academic course for dual credittaught on a postsecondary campus.

3) Examine the impact on NAEP composite reading scores of students who enrolled in an English/language arts academic course for dual credit taught through distance learning.

Our theoretical framework for this research adopts a scientific inquiry-based approach. The framework was described in great details in The Impact of Conversations on Fourth Grade Reading Performance - What NAEP Data Explorer Tells? (Bond \& Zhang, 2017). In summary, the research methods combined the inquiry process with scientific knowledge, reasoning, and critical thinking. We started with an extensive exploration of the dataset, and that led to the designing of the research questions. The research questions further guided us to mine the data with great in-depth.

\section{LITERATURE REVIEW}

Students entering high school are presented with various learning pathways that eventually lead to a diploma.As schools continue to evaluate post-secondary expectations, the focus on student interests and their educational development plan (EDP) assists with scheduling and proper placement within general, advanced, and vocational courses for high school credit. The nature and quality of courses students take impacts their readiness for either college or career entrance (Conley, 2008). Graduation requirements provide a framework, much like a ladder students must climb towards completion. Within that framework are multiple pathways which afford opportunity for college and career exploration and a frame of reference for students as they select specific courses during the scheduling process. Many factors play a part, including previous and current student achievement and credit earned.One specific area of rapid growing interest is college dual credit courses for high school students. Dual credit 
Rebekah Redmer, and Mingyuan Zhang

enrollment at the college or postsecondary level offers a rigorous academic experience to high school students and supports the connection to bridge students to higher education (Grubb, Scott, and Good, 2017).

\subsection{BENEFITS OF DUAL ENROLLMENT FOR HIGH SCHOOL STUDENTS}

As dual enrollment becomes more available to high school students, they are experiencing benefits associated with electing dual credit while also counting towards high school graduation requirements. Dual enrollment historically has been offered to students with high academic achievement, moving beyond the secondary curriculum offered within their school (Howley et al., 2013).It has become an increasingly popular option for students to consider as the awarding of credit is based on the entire course and grade earned, rather than a one-day exam such as Advanced Placement (AP) courses (Herbert, 2001). School counselors and administrators are spending a greater amount of time investing in dual credit opportunities for students as it provides appeal for academic advancement beyond the school or district.Benefits such as college level exposure and financial savings are becoming increasingly known to students and their parent(s)/guardian(s) to select when scheduling courses.

\subsubsection{COLLEGE LEVEL EXPOSURE AND RIGOR}

Academic behaviors necessary for a successful college experience require a student to have a greater selfawareness, self-monitoring, and self-control (Conley, 2011). Students who are able to experience a college level course, specifically one that is taught for college credit and transcripted as such, are exposed to the environment or rigor required for college (Kanny, 2015). Students who participate in dual enrollment courses or programs have reportedly been identified as more likely to graduate from high school, be accepted and enroll in college(Zuidema and Eames, 2014), have higher college GPAs, are less likely to be placed in a remedial math course, and are more likely to persist and earn a degree (Hanson et al., 2015).The overall academic rigor or strength of a student's high school curricular experience "counts more than anything else in precollegiate history in providing momentum toward completing a bachelor's degree" (Adelman, 2006).

\subsubsection{FINANCIAL SAVINGS}

Dual enrollment is becoming increasingly available to a wider range of students, reaching those who would otherwise not have access to college due to socioeconomic status (Kanny, 2015). Many states have dual enrollment pupil accounting and membership standards in which state school aid pays for a portion or all of the dual credit course.In Michigan specifically, according to the Pupil Accounting Manual (2019), students meeting the qualifying college readiness scores may enroll in up to 10 dual credit courses throughout high school and attend a college or other postsecondary institution. The State of Michigan will cover the cost up to $1 / 12$ of state aid, which last year equated to $\$ 675$ per course (for students taking 6 courses on a semester schedule). If the cost of the course falls below this cap, high schools would also be able to cover the cost of books and technology fees as well (Pupil Accounting Manual, 2019). Across the United States in 2020-2011, high schools reported that students enrolled in dual credit courses that were academically focused, 93\% reported their students were awarded postsecondary credit immediately when completing the course (Thomas, Marken, Gray, and Lewis, 2013). This is a tremendous savings when considering transfer credit and overall costs related to undergraduate tuition.

\subsection{CHALLENGES OF DUAL ENROLLMENT FOR HIGH SCHOOL STUDENTS}

With dual enrollment expanding to provide access to students, some have increased their attention to the rigor and authenticity of these courses (Hughes and Edwards, 2012). In order to reduce barriers associated with access and transportation, more high schools have entered into agreements with colleges and universities, who employ high school teachers to become part-time adjunct faculty, enabling students to attend the dual credit courses on their high school campus (Howley et al., 2013). The experience and views of teachers who cross over between secondary and postsecondary institutions at times experience communication constraints (Howley et al., 2013), which may contribute to a lack of support for students learning in both environments. Additionally, access and support regarding parental involvement, although transitional as a student progresses towards graduation, still is considered 
important. Lack of parental access or view of assignments in a college course, even if they do not fully understand them (Adelman, 2005), may impact the support and motivation resulting from parental involvement that could contribute to the completion of postsecondary coursework. The unfortunate reality for many students is the absence of adequate opportunity to learn in some high schools, as well as the exclusion of some groups of students over others (Adelman, 2006). Challenges related to student preparedness have emerged as a result of expanding access to dual enrollment courses. One study identified struggles associated with students' lack of academic skills and concerns with affective adjustment to the college environment (Hughes and Edwards, 2012).

Students who enroll and successfully complete a dual college enrollment course for credit have a choice in some states to determine how this course is reflected on their official transcripts. In any case, taking a college course may be perceived as a way to build the student's transcript (Howley et al., 2013), especially if they have their sights set on applying to a specific college or university. This at times may cause tension with transfer credits, which may change each year; for example, at prestigious postsecondary institutions such as the University of Michigan, embedded within the application there is a question specifically asking if the dual credit course was earned at a college campus, at a high school campus, or online. Similar tension may also be present when considering tuition and funding. The recruitment of dual enrolled students by postsecondary institutions may add to the economic dynamic that exists with this opportunity, knowing the funding will be lost to the college institution as a financial consequence, which may dissuade high school professionals from supporting dual enrollment efforts (Howley et al., 2013).

\subsection{THE IMPORTANCE OF SCHOOL PROFESSIONALS IN PROVIDING DUAL ENROLLMENT FOR HIGH SCHOOL STUDENTS}

Teachers, counselors, and principals all have a direct impact on the dual enrollment experience for students within their school or district, and their combined efforts, perceptions and involvement are important when it comes to successfully offering this opportunity to students (Hanson et al., 2015). Even with supportive evidence regarding the benefits of dual enrollment for high school students, the feasibility surrounding the organizational mission, culture, and intersection of institutions (secondary and higher education), requires considerable planning and evaluation efforts (Howley et al., 2013) to ensure successful access to students. In Martinez et al. (2018), the authors in this study identify strategic leadership as an important finding when planning a dual enrollment program within a high school.They state, "this [strategic leadership] type of approach requires administrators to leverage their resources, understand current trends, and identify instructional needs" (p529). With organizational systems in place to facilitate dual enrollment programming, students may be championed by the teachers as they serve to support content, the counselors as they serve as liaisons between the secondary and postsecondary institutions, and the building principals as they analyze and adjust programming based on enrollment patterns and academic outcomes (Hanson et al., 2015).

\section{MATERIALS AND METHODS}

National Center for Educational Statistics (NCES) is a division of the U.S. Department of Education's Institute of Education Sciences. The NCES oversees "The Nation's Report Card" through a congressionally mandated project called the National Assessment of Educational Progress (NAEP) (NCES, 2018). The NAEP is a continuous national assessment that is used to measure elementary and secondary student knowledge in subject areas that include the arts, civics, economics, geography, mathematics, reading, science, technology and engineering, literacy, U.S. history, and writing (NCES, 2018b).

Most states conduct standardized student assessments that reflect curriculum standards, of which predetermined proficiency scores are used as a measure of accountability for districts or schools. The NAEP, unlike state assessments, does not provide individual student achievement data, but rather is used nationally as a comparison between states and similar participating regions.The NAEP literature and reading assessments for the nation began in 1970 with students in grades 4, 8, and 12 (NCES, 2020).In 2015, approximately 18,700 12th grade students took the NAEP reading assessment, which can be compared to previous reading assessments dating back to 1992 (NCES, 2016) with scores representing average student proficiency achievement levels. 
Rebekah Redmer, and Mingyuan Zhang

\subsection{SAMPLING PROCESS}

Unlike many state assessments, the NAEP does not require every student within a school or district to take the assessment. A sampling frame is created using the Common Core of Data (CCD) and the Private School Survey (PSS), identifying a sample of students who represent the student population, as well as individual states and districts (Focus on NAEP: Sampling). The school selection process is strategic, and following confirmation of eligibility, students within the school are selected for the national assessment in subject areas based on grade; either 4, 8 or 12 . All students may be selected randomly. After the identification of participants within the school, students are tasked with answering questions within a single subject area; typically, 30 students per grade are selected from each grade per subject. It is important to note: students with disabilities and English language learners (ELL) qualify for accommodations offered by the NEAP program, should they be selected (Focus on NAEP: Sampling). For the purpose of this study, the focus is on the NAEP reading assessment for grade 12 in the final stage of the student's K-12 academic career.

\subsubsection{NAEP BACKGROUND QUESTIONNAIRES}

Students who participated in the NAEP assessment, along with teachers and school administrators at the selected school, are provided the opportunity to complete voluntary survey questionnaires. These questionnaires further collect data to better support contextual understanding among researchers (NCES, 2018b). The three different types of survey questionnaires are:

1) Student: collects information regarding demographics, educational experiences, and opportunities outside of the classroom. Students who participated in the NAEP assessment complete this questionnaire.

2) Teacher: collects information regarding teacher professional development and training, along with instructional practices. Teachers who instruct within the NAEP subject area assessed complete this questionnaire.

3) School: collects information regarding school policy and practices, including characteristics pertaining to specific sub-categories of students such as ELL and students identified with disabilities.

\subsection{DATA ANALYSIS}

Using the NAEP Data Explorer, the present study identified grade 12 reading proficiency scores and questionnaire items on factors relating to the location of earned dual enrollment credit within an ELA course.The threespecific variables are presented in Table1.

Table 1: School-Reported NAEP Variables Chosen for Analysis

School Survey Question: Approximately what percentage of students in this year's graduation class has enrolled in an English/language arts academic course for dual credit taught at the following locations?

\begin{tabular}{|l|l|l} 
On your high school campus & On a postsecondary campus & Through distance learning
\end{tabular}

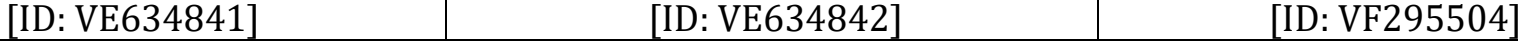

The present study observed the average scale scores for the NAEP reading assessment.The three variables selected for analysis were presented in a 7-point Likert-type scale indicating a percentage range of for each: 0\%, 15\%, 6-10\%, 11-25\%, 26-50\%,51-75\%, and over 75\%. Using the NAEP Data Explorer, descriptive analysis and independent $t$ tests are generated and used to compare the average scale score with each variable.

\section{RESULTS}

The NAEP Data Explorer provided data used for this study, specifically regarding instructional location of dual credit courses and reading scores for 12th grade students in 2015. The research focused on examining dual credit offered at specific locations: the high school campus, a postsecondary campus, and through distance learning. The average scale score of the 12th grade NAEP reading assessment was 287 (SD=41), with a scale ranging from 0-500. Results were reported by the school administrator and provided through a NAEP school questionnaire, identifying 
the percentage of students in the graduating class that enrolled in an English/language arts (ELA) academic course for dual credit. Each of the three locations where dual credit was earned (high school campus, postsecondary campus, or distance learning), provide the average scale score in relationship to the range of 12 th grade student enrollment percentages, 0\%, 1-5\%, 6-10\%, 11-25\%, 26-50\%, 51-75\%, and over 75\% in dual credit. Presented below are research questions and the average mean scores, along with significance testing results generated by the NAEP Explorer. Cohen's d was calculated using the University of Colorado's effect sized website https://www.uccs.edu/lbecker/ and provided within this results section.

\section{Research Question 1}

Examine the impact on NAEP composite reading scores of students who enrolled in an ELA academic course for dual credit taught on a high school campus.

Table 2: Average national scale scores and standard deviations for grade 12 reading in 2015, by students in a dual credit ELA course taught on their high school campus

\begin{tabular}{|c|c|c|}
\hline $\begin{array}{c}\text { Students (\%) in Dual Credit English/language Arts High School Course - } \\
\text { High School Campus }\end{array}$ & $\begin{array}{c}\text { Average Scale } \\
\text { Score }\end{array}$ & $\begin{array}{c}\text { Standard } \\
\text { Deviation }\end{array}$ \\
\hline $0 \%$ & 287 & 41 \\
\hline $1-5 \%$ & 284 & 41 \\
\hline $6-10 \%$ & 288 & 39 \\
\hline $11-25 \%$ & 288 & 39 \\
\hline $26-50 \%$ & 291 & 40 \\
\hline $51-75 \%$ & 299 & 38 \\
\hline Over 75\% & 286 & 43 \\
\hline
\end{tabular}

Note: source is from U.S. Department of Education, Institute of Education Sciences, National Center for Education Statistics, National Assessment of Educational Progress (NAEP), 2015 Reading assessment

NAEP reading scores for 12 th grade students who enrolled in a dual credit course on a high school campus yielded the highest average score with $26-50 \%$ participation $(M=291, S D=40)$, and the lowest average score when participation in dual credit is between $1-5 \%(M=284, S D=41)$. There was no significant difference in reading scores when compared to each percentage category of 12th grade students participating in a dual credit ELA course on a high school campus. A series of t-tests were conducted with the NAEP Data Explorer to identify any observation of significance between the percentage of students enrolled in a dual credit ELA course on their high school campus and achievement scores on the 2015 reading test.

Table 3: Difference in average scale scores between variables, for students in dual credit ELA high school

\begin{tabular}{|c|c|c|c|c|c|c|c|}
\hline & $\begin{array}{c}0 \% \\
(287)\end{array}$ & $\begin{array}{l}1-5 \% \\
(284)\end{array}$ & $\begin{array}{l}6-10 \% \\
(288)\end{array}$ & $\begin{array}{c}11-25 \% \\
(288)\end{array}$ & $\begin{array}{c}26-50 \% \\
(291)\end{array}$ & $\begin{array}{c}51-75 \% \\
(299)\end{array}$ & $\begin{array}{c}\text { Over } 75 \% \\
(286)\end{array}$ \\
\hline $\begin{array}{c}0 \% \\
(287)\end{array}$ & & $\begin{array}{c}x \\
\text { Diff }=3 \\
\text { P-value }= \\
0.1704 \\
\text { Family size } \\
=21\end{array}$ & $\begin{array}{c}\mathrm{x} \\
\text { Diff }=-1 \\
\text { P-value }= \\
0.5441 \\
\text { Family size } \\
=21\end{array}$ & $\begin{array}{c}\mathrm{x} \\
\text { Diff }=0 \\
\text { P-value }= \\
0.8155 \\
\text { Family size } \\
=21\end{array}$ & $\begin{array}{c}\mathrm{x} \\
\text { Diff }=-4 \\
\text { P-value }= \\
0.1197 \\
\text { Family size } \\
=21\end{array}$ & $\begin{array}{c}x \\
\text { Diff }=-12 \\
\text { P-value }= \\
0.1555 \\
\text { Family size } \\
=21\end{array}$ & $\begin{array}{c}\mathrm{x} \\
\text { Diff }=2 \\
\text { P-value }= \\
0.7084 \\
\text { Family size } \\
=21\end{array}$ \\
\hline $\begin{array}{l}1-5 \% \\
(284)\end{array}$ & $\begin{array}{c}\mathrm{X} \\
\text { Diff }=-3 \\
\text { P-value }= \\
0.1704 \\
\text { Family size } \\
=21\end{array}$ & & $\begin{array}{c}\mathrm{x} \\
\text { Diff }=-4 \\
\text { P-value }= \\
0.1037 \\
\text { Family size } \\
=21\end{array}$ & $\begin{array}{c}\mathrm{X} \\
\text { Diff }=-4 \\
\text { P-value }= \\
0.1730 \\
\text { Family size } \\
=21\end{array}$ & $\begin{array}{c}x \\
\text { Diff }=-8 \\
\text { P-value }= \\
0.0238 \\
\text { Family size } \\
=21\end{array}$ & $\begin{array}{c}\mathrm{x} \\
\text { Diff }=-15 \\
\text { P-value }= \\
0.0794 \\
\text { Family size } \\
=21\end{array}$ & $\begin{array}{c}x \\
\text { Diff }=-2 \\
\text { P-value }= \\
0.7003 \\
\text { Family size } \\
=21\end{array}$ \\
\hline $\begin{array}{c}6-10 \% \\
(288)\end{array}$ & $\begin{array}{c}\mathrm{X} \\
\text { Diff }=1\end{array}$ & $\begin{array}{c}x \\
\text { Diff }=4\end{array}$ & & $\begin{array}{c}X \\
\text { Diff }=1\end{array}$ & $\begin{array}{c}x \\
\text { Diff }=-3\end{array}$ & $\begin{array}{c}x \\
\text { Diff }=-10\end{array}$ & $\begin{array}{c}x \\
\text { Diff }=3\end{array}$ \\
\hline
\end{tabular}


Rebekah Redmer, and Mingyuan Zhang

\begin{tabular}{|c|c|c|c|c|c|c|c|}
\hline & $\begin{array}{c}\text { P-value }= \\
0.5441 \\
\text { Family size } \\
=21\end{array}$ & $\begin{array}{c}\text { P-value }= \\
0.1037 \\
\text { Family size } \\
=21\end{array}$ & & $\begin{array}{c}\text { P-value }= \\
0.7557 \\
\text { Family size } \\
=21\end{array}$ & $\begin{array}{c}\text { P-value }= \\
0.3203 \\
\text { Family size } \\
=21\end{array}$ & $\begin{array}{c}\text { P-value }= \\
0.2056 \\
\text { Family size } \\
=21\end{array}$ & $\begin{array}{c}\text { P-value }= \\
0.5240 \\
\text { Family size } \\
=21\end{array}$ \\
\hline $\begin{array}{c}11-25 \% \\
(288)\end{array}$ & $\begin{array}{c}\mathrm{x} \\
\text { Diff }=0 \\
\text { P-value }= \\
0.8155 \\
\text { Family size } \\
=21\end{array}$ & $\begin{array}{c}x \\
\text { Diff }=4 \\
\text { P-value }= \\
0.1730 \\
\text { Family size } \\
=21\end{array}$ & $\begin{array}{c}x \\
\text { Diff }=-1 \\
\text { P-value }= \\
0.7557 \\
\text { Family size } \\
=21\end{array}$ & & $\begin{array}{c}x \\
\text { Diff }=-4 \\
\text { P-value }= \\
0.2134 \\
\text { Family size } \\
=21\end{array}$ & $\begin{array}{c}\mathrm{x} \\
\text { Diff }=-11 \\
\text { P-value }= \\
0.1760 \\
\text { Family size } \\
=21\end{array}$ & $\begin{array}{c}x \\
\text { Diff }=2 \\
\text { P-value }= \\
0.6428 \\
\text { Family size } \\
=21\end{array}$ \\
\hline $\begin{array}{c}26-50 \% \\
(291)\end{array}$ & $\begin{array}{c}\mathrm{X} \\
\text { Diff }=4 \\
\text { P-value }= \\
0.1197 \\
\text { Family size } \\
=21\end{array}$ & $\begin{array}{c}x \\
\text { Diff }=8 \\
\text { P-value }= \\
0.0238 \\
\text { Family size } \\
=21\end{array}$ & $\begin{array}{c}\mathrm{X} \\
\text { Diff }=3 \\
\text { P-value }= \\
0.3203 \\
\text { Family size } \\
=21\end{array}$ & $\begin{array}{c}\mathrm{x} \\
\text { Diff }=4 \\
\text { P-value }= \\
0.2134 \\
\text { Family size } \\
=21\end{array}$ & & $\begin{array}{c}x \\
\text { Diff }=-7 \\
\text { P-value }= \\
0.3724 \\
\text { Family size } \\
=21\end{array}$ & $\begin{array}{c}\mathrm{x} \\
\text { Diff }=6 \\
\text { P-value }= \\
0.2215 \\
\text { Family size } \\
=21\end{array}$ \\
\hline $\begin{array}{c}51-75 \% \\
(299)\end{array}$ & $\begin{array}{c}\text { x } \\
\text { Diff = } 12 \\
\text { P-value }= \\
0.1555 \\
\text { Family size } \\
=21\end{array}$ & $\begin{array}{c}x \\
\text { Diff }=15 \\
\text { P-value }= \\
0.0794 \\
\text { Family size } \\
=21\end{array}$ & $\begin{array}{c}x \\
\text { Diff }=10 \\
\text { P-value }= \\
0.2056 \\
\text { Family size } \\
=21\end{array}$ & $\begin{array}{c}\mathrm{x} \\
\text { Diff = } 11 \\
\text { P-value }= \\
0.1760 \\
\text { Family size } \\
=21\end{array}$ & $\begin{array}{c}x \\
\text { Diff }=7 \\
\text { P-value }= \\
0.3724 \\
\text { Family size } \\
=21\end{array}$ & & $\begin{array}{c}x \\
\text { Diff }=13 \\
\text { P-value }= \\
0.1406 \\
\text { Family size } \\
=21\end{array}$ \\
\hline $\begin{array}{l}\text { Over } \\
75 \% \\
(286)\end{array}$ & $\begin{array}{c}\mathrm{X} \\
\text { Diff }=-2 \\
\text { P-value }= \\
0.7084 \\
\text { Family size } \\
=21\end{array}$ & $\begin{array}{c}x \\
\text { Diff }=2 \\
\text { P-value }= \\
0.7003 \\
\text { Family size } \\
=21\end{array}$ & $\begin{array}{c}\mathrm{x} \\
\text { Diff }=-3 \\
\text { P-value }= \\
0.5240 \\
\text { Family size } \\
=21\end{array}$ & $\begin{array}{c}\mathrm{X} \\
\text { Diff }=-2 \\
\text { P-value }= \\
0.6428 \\
\text { Family size } \\
=21\end{array}$ & $\begin{array}{c}x \\
\text { Diff }=-6 \\
\text { P-value }= \\
0.2215 \\
\text { Family size } \\
=21\end{array}$ & $\begin{array}{c}\mathrm{x} \\
\text { Diff }=-13 \\
\text { P-value }= \\
0.1406 \\
\text { Family size } \\
=21\end{array}$ & \\
\hline
\end{tabular}

$<$ Significantly lower

$>$ Significantly higher

$x$ No significant difference

Note: within jurisdiction comparisons on any given year are dependent with an alpha level of 0.05

Table 4: Effect sizes of significant mean score differences between 12 grade enrollment percentages of students enrolled in an ELA dual credit course on their high school campus, and reading scores

\begin{tabular}{|c|c|c|}
\hline Frequency 1 & Frequency 2 & Cohen's $d$ \\
\hline $\begin{array}{c}0 \% \text { enrollment } \\
(\mathrm{M}=287, \mathrm{SD}=41)\end{array}$ & $\begin{array}{c}1-5 \% \text { enrollment } \\
(\mathrm{M}=284, \mathrm{SD}=41)\end{array}$ & 0.073 \\
\hline $\begin{array}{c}6-10 \% \text { enrollment } \\
(\mathrm{M}=288, \mathrm{SD}=39)\end{array}$ & $\begin{array}{c}0 \% \text { enrollment } \\
(\mathrm{M}=287, \mathrm{SD}=41)\end{array}$ & 0.024 \\
\hline $\begin{array}{c}11-25 \% \text { enrollment } \\
(\mathrm{M}=288, \mathrm{SD}=39)\end{array}$ & $\begin{array}{c}0 \% \text { enrollment } \\
(\mathrm{M}=287, \mathrm{SD}=41)\end{array}$ & 0.024 \\
\hline $\begin{array}{c}26 \%-50 \% \text { enrollment } \\
(\mathrm{M}=291, \mathrm{SD}=40)\end{array}$ & $\begin{array}{c}0 \% \text { enrollment } \\
(\mathrm{M}=287, \mathrm{SD}=41)\end{array}$ & 0.099 \\
\hline $\begin{array}{c}51 \%-75 \% \text { enrollment } \\
(\mathrm{M}=299, \mathrm{SD}=38)\end{array}$ & $\begin{array}{c}0 \% \text { enrollment } \\
(\mathrm{M}=287, \mathrm{SD}=41)\end{array}$ & 0.304 \\
\hline $0 \%$ enrollment & Over 75\% enrollment & 0.024 \\
$(\mathrm{M}=287, \mathrm{SD}=41)$ & $(\mathrm{M}=286, \mathrm{SD}=43$ & \\
\hline $51 \%-75 \%$ enrollment & $1-5 \%$ enrollment & 0.379 \\
$(\mathrm{M}=299, \mathrm{SD}=38)$ & $(\mathrm{M}=284, \mathrm{SD}=41)$ & \\
\hline
\end{tabular}


Identification of effect size, as set by Cohen, may be determined by small (0.2), medium (0.5), and large (0.8). Effect size was calculated using enrollment percentages for dual credit earned on a high school campus, in relationship to the average scale scores of reading. Comparing $0 \%$ of students to $6-10 \%$ and $11-25 \%$ of students taking a dual credit ELA course on a high school campus yielded the smallest effect size (d=0.024). Although considered small, the highest yielding effect size was observed when calculating Cohen's d for 51\%-75\% and 1-5\% of students taking dual credit $(\mathrm{d}=0.39)$.

\section{Research Question 2}

Examine the impact on NAEP composite reading scores of students who enrolled in an ELA academic course for dual credit taught on a postsecondary campus.

Table 5: Average national scale scores and standard deviations for grade 12 reading in 2015, by students in a dual credit ELA course taught on a postsecondary campus

\begin{tabular}{|c|c|c|}
\hline $\begin{array}{c}\text { Students (\%) in Dual Credit English/language Arts Course - } \\
\text { Postsecondary Campus }\end{array}$ & $\begin{array}{c}\text { Average Scale } \\
\text { Score }\end{array}$ & $\begin{array}{c}\text { Standard } \\
\text { Deviation }\end{array}$ \\
\hline $0 \%$ & 287 & 41 \\
\hline $1-5 \%$ & 287 & 40 \\
\hline $6-10 \%$ & 289 & 39 \\
\hline $11-25 \%$ & 286 & 37 \\
\hline $26-50 \%$ & 286 & 47 \\
\hline $51-75 \%$ & $\ddagger$ & $\ddagger$ \\
\hline Over $75 \%$ & $\ddagger$ & $\ddagger$ \\
\hline
\end{tabular}

NAEP reading scores for 12 th grade students who enrolled in a dual credit course on a postsecondary campus yielded the highest average score with $6-10 \%$ enrollment $(M=289, S D=39)$, and the lowest average score when enrollment in dual credit is between $11-25 \%$ and $26-50 \%(M=264, S D=47)$. There was no significant difference in reading scores when compared to each percentage category of 12th grade students participating in an ELA dual credit course on a postsecondary campus. A series of t-tests were conducted with the NAEP Data Explorer to identify any observation of significance between the percentage of students enrolled in a dual credit ELA course on a postsecondary campus and achievement scores on the 2015 reading test. A significance test could not be conducted for student enrollment percentages $51-75 \%$ and over $75 \%$.

Table 6: Difference in average scale scores between variables, for students in dual credit ELA postsecondary

\begin{tabular}{|c|c|c|c|c|c|c|c|}
\hline \multicolumn{8}{|c|}{ courses } \\
\hline & $0 \%$ & $1-5 \%$ & $6-10 \%$ & $11-25 \%$ & $26-50 \%$ & $\begin{array}{c}51- \\
75 \% \\
\end{array}$ & $\begin{array}{l}\text { Over } \\
75 \% \\
\end{array}$ \\
\hline $0 \%$ & & $\begin{array}{c}\mathrm{X} \\
\text { Diff }=0 \\
\text { P-value }= \\
0.7565 \\
\text { Family size }= \\
10\end{array}$ & $\begin{array}{c}\mathrm{X} \\
\text { Diff }=-2 \\
\text { P-value }= \\
0.3772 \\
\text { Family size }= \\
10\end{array}$ & $\begin{array}{c}\mathrm{x} \\
\text { Diff }=1 \\
\text { P-value }= \\
0.7252 \\
\text { Family size = } \\
10\end{array}$ & $\begin{array}{c}\mathrm{x} \\
\text { Diff }=1 \\
\text { P-value }= \\
0.9067 \\
\text { Family size = } \\
10\end{array}$ & $\neq$ & $\neq$ \\
\hline $1-5 \%$ & $\begin{array}{c}\mathrm{X} \\
\text { Diff }=0 \\
\text { P-value }= \\
0.7565 \\
\text { Family size = } \\
10\end{array}$ & & $\begin{array}{c}\mathrm{x} \\
\text { Diff }=-3 \\
\text { P-value }= \\
0.2910 \\
\text { Family size = } \\
10\end{array}$ & $\begin{array}{c}\mathrm{x} \\
\text { Diff }=1 \\
\text { P-value }= \\
0.8300 \\
\text { Family size = } \\
10\end{array}$ & $\begin{array}{c}\mathrm{x} \\
\text { Diff }=1 \\
\text { P-value }= \\
0.9383 \\
\text { Family size = } \\
10\end{array}$ & $\neq$ & $\ddagger$ \\
\hline $6-10 \%$ & $\begin{array}{c}\mathrm{X} \\
\text { Diff }=2 \\
\text { P-value }= \\
0.3772\end{array}$ & $\begin{array}{c}\mathrm{X} \\
\text { Diff }=3 \\
\mathrm{P}-\mathrm{value}= \\
0.2910\end{array}$ & & $\begin{array}{c}\mathrm{x} \\
\text { Diff }=3 \\
\text { P-value }= \\
0.3993\end{array}$ & $\begin{array}{c}\mathrm{X} \\
\text { Diff }=4 \\
\text { P-value }= \\
0.7701\end{array}$ & $\neq$ & $\neq$ \\
\hline
\end{tabular}


Rebekah Redmer, and Mingyuan Zhang

\begin{tabular}{|c|c|c|c|c|c|c|c|}
\hline & $\begin{array}{c}\text { Family size }= \\
10\end{array}$ & $\begin{array}{c}\text { Family size = } \\
10\end{array}$ & & $\begin{array}{c}\text { Family size }= \\
10\end{array}$ & $\begin{array}{c}\text { Family size }= \\
10\end{array}$ & & \\
\hline $11-25 \%$ & $\begin{array}{c}\mathrm{x} \\
\text { Diff }=-1 \\
\text { P-value }= \\
0.7252 \\
\text { Family size }= \\
10\end{array}$ & $\begin{array}{c}\mathrm{x} \\
\text { Diff }=-1 \\
\text { P-value }= \\
0.8300 \\
\text { Family size }= \\
10\end{array}$ & $\begin{array}{c}\mathrm{x} \\
\text { Diff }=-3 \\
\text { P-value }= \\
0.3993 \\
\text { Family size }= \\
10\end{array}$ & & $\begin{array}{c}\mathrm{X} \\
\text { Diff }=0 \\
\text { P-value }= \\
0.9889 \\
\text { Family size }= \\
10\end{array}$ & $\neq$ & $\neq$ \\
\hline $26-50 \%$ & $\begin{array}{c}\mathrm{x} \\
\text { Diff }=-1 \\
\text { P-value }= \\
0.9067 \\
\text { Family size = } \\
10\end{array}$ & $\begin{array}{c}\mathrm{x} \\
\text { Diff }=-1 \\
\text { P-value }= \\
0.9383 \\
\text { Family size = } \\
10\end{array}$ & $\begin{array}{c}\mathrm{x} \\
\text { Diff }=-4 \\
\text { P-value }= \\
0.7701 \\
\text { Family size }= \\
10\end{array}$ & $\begin{array}{c}\mathrm{x} \\
\text { Diff }=0 \\
\text { P-value }= \\
0.9889 \\
\text { Family size = } \\
10\end{array}$ & & $\neq$ & $\neq$ \\
\hline $51-75 \%$ & $\neq$ & $\neq$ & $\neq$ & $\neq$ & $\ddagger$ & & $\neq$ \\
\hline $\begin{array}{l}\text { Over } \\
75 \%\end{array}$ & $\neq$ & $\neq$ & $\neq$ & $\neq$ & $\neq$ & $\neq$ & \\
\hline
\end{tabular}

$<$ Significantly lower

$>$ Significantly higher

$\mathrm{x}$ No significant difference

‡ A significance test could not be performed because reporting standards were not met, or appropriate standard errors could not be calculated for one or more estimates in the test.

Note: within jurisdiction comparisons on any given year are dependent with an alpha level of 0.05

Table 7: Effect sizes of significant mean score differences between 12 grade enrollment percentages of students enrolled in an ELA dual credit course on a postsecondary campus, and reading scores.

\begin{tabular}{|c|c|c|}
\hline Frequency 1 & Frequency 2 & Cohen's $d$ \\
\hline $\begin{array}{c}0 \% \text { enrollment } \\
(\mathrm{M}=287, \mathrm{SD}=41)\end{array}$ & $\begin{array}{c}1-5 \% \text { enrollment } \\
(\mathrm{M}=287, \mathrm{SD}=40)\end{array}$ & 0 \\
\hline $\begin{array}{c}6-10 \% \text { enrollment } \\
(\mathrm{M}=289, \mathrm{SD}=39)\end{array}$ & $\begin{array}{c}0 \% \text { enrollment } \\
(\mathrm{M}=287, \mathrm{SD}=41)\end{array}$ & 0.049 \\
\hline $\begin{array}{c}0 \% \text { enrollment } \\
(\mathrm{M}=287, \mathrm{SD}=41)\end{array}$ & $\begin{array}{c}11-25 \% \text { enrollment } \\
(\mathrm{M}=286, \mathrm{SD}=37)\end{array}$ & 0.025 \\
\hline $6-10 \%$ enrollment & $\begin{array}{c}25-50 \% \text { enrollment } \\
(\mathrm{M}=286, \mathrm{SD}=47)\end{array}$ & 0.069 \\
\hline
\end{tabular}

Identification of effect size, as set by Cohen, are determined by small (0.2), medium (0.5), and large (0.8). Effect size was determined through calculating Cohen's d using enrollment percentages for dual credit earned on a postsecondary campus, in relationship to the average scale scores of reading. All effect sizes were considered small.

\section{Research Question 3}

Examine the impact on NAEP composite reading scores of students who enrolled in an ELA academic course for dual credit taught through distance learning.

Table 8: Average national scale scores and standard deviations for grade 12 reading in 2015, by students in a dual credit ELA course taught through distance learning.

\begin{tabular}{|c|c|c|}
\hline $\begin{array}{c}\text { Students (\%) in Dual Credit English/Language Arts Course - Distance } \\
\text { Learning }\end{array}$ & $\begin{array}{c}\text { Average Scale } \\
\text { Score }\end{array}$ & $\begin{array}{c}\text { Standard } \\
\text { Deviation }\end{array}$ \\
\hline $0 \%$ & 287 & 41 \\
\hline $1-5 \%$ & 288 & 39 \\
\hline $6-10 \%$ & 286 & 40 \\
\hline $11-25 \%$ & 303 & 35 \\
\hline $26-50 \%$ & 281 & 35 \\
\hline
\end{tabular}




\begin{tabular}{|c|c|c|}
\hline $51-75 \%$ & $\neq$ & $\neq$ \\
\hline Over $75 \%$ & $\neq$ & $\neq$ \\
\hline
\end{tabular}

NAEP reading scores for 12 th grade students who enrolled in a dual credit course through distance learning yielded the highest average score with $11-25 \%$ enrollment $(M=303, S D=35)$, and the lowest average score when enrollment in dual credit was between $26-50 \%(M=281, S D=35)$. There was a significant difference in reading scores when compared to each percentage category of 12th grade students enrolled in a dual credit ELA distance learning course. A series of t-tests were conducted with the NAEP Data Explorer to identify observations of significance between the percentage of students enrolled in a dual credit ELA distance learning course and achievement scores on the 2015 reading test. A significance test could not be conducted for student enrollment percentages $51-75 \%$ and over $75 \%$.

Table 9: Difference in average scale scores between variables, for students in dual credit ELA distance learning courses.

\begin{tabular}{|c|c|c|c|c|c|c|c|}
\hline & $0 \%$ & $1-5 \%$ & $6-10 \%$ & $11-25 \%$ & $26-50 \%$ & $\begin{array}{c}51- \\
75 \%\end{array}$ & $\begin{array}{l}\text { Over } \\
75 \%\end{array}$ \\
\hline $0 \%$ & & $\begin{array}{c}\mathrm{x} \\
\text { Diff }=-1 \\
\text { P-value }= \\
0.3521 \\
\text { Family size = } \\
10\end{array}$ & $\begin{array}{c}\mathrm{X} \\
\text { Diff }=1 \\
\text { P-value }= \\
0.9050 \\
\text { Family size }= \\
10\end{array}$ & $\begin{array}{c}< \\
\text { Diff }=-16 \\
\text { P-value }= \\
0.0081 \\
\text { Family size }= \\
10\end{array}$ & $\begin{array}{c}\mathrm{x} \\
\text { Diff }=6 \\
\text { P-value }= \\
0.2337 \\
\text { Family size }= \\
10\end{array}$ & $\neq$ & $\neq$ \\
\hline $1-5 \%$ & $\begin{array}{c}\mathrm{x} \\
\text { Diff }=1 \\
\text { P-value }= \\
0.3521 \\
\text { Family size = } \\
10\end{array}$ & & $\begin{array}{c}\mathrm{x} \\
\text { Diff }=2 \\
\text { P-value }= \\
0.6827 \\
\text { Family size = } \\
10\end{array}$ & $\begin{array}{c}<< \\
\text { Diff }=-15 \\
\text { P-value }= \\
0.0144 \\
\text { Family size = } \\
10\end{array}$ & $\begin{array}{c}\mathrm{x} \\
\text { Diff }=7 \\
\text { P-value }= \\
0.1519 \\
\text { Family size = } \\
10\end{array}$ & $\neq$ & $\neq$ \\
\hline $6-10 \%$ & $\begin{array}{c}\mathrm{X} \\
\text { Diff }=-1 \\
\text { P-value }= \\
0.9050 \\
\text { Family size }= \\
10\end{array}$ & $\begin{array}{c}\mathrm{x} \\
\text { Diff }=-2 \\
\text { P-value }= \\
0.6827 \\
\text { Family size }= \\
10\end{array}$ & & $\begin{array}{c}\mathrm{x} \\
\text { Diff }=-17 \\
\text { P-value }= \\
0.0228 \\
\text { Family size }= \\
10\end{array}$ & $\begin{array}{c}\mathrm{x} \\
\text { Diff }=5 \\
\text { P-value }= \\
0.4161 \\
\text { Family size = } \\
10\end{array}$ & $\neq$ & $\neq$ \\
\hline $11-25 \%$ & $\begin{array}{c}>> \\
\text { Diff }=16 \\
\text { P-value }= \\
0.0081 \\
\text { Family size = } \\
10\end{array}$ & $\begin{array}{c}> \\
\text { Diff }=15 \\
\text { P-value }= \\
0.0144 \\
\text { Family size = } \\
10\end{array}$ & $\begin{array}{c}\mathrm{x} \\
\text { Diff }=17 \\
\text { P-value }= \\
0.0228 \\
\text { Family size = } \\
10 \\
\end{array}$ & & $\begin{array}{c}> \\
\text { Diff }=22 \\
\text { P-value }= \\
0.0042 \\
\text { Family size = } \\
10\end{array}$ & $\neq$ & $\neq$ \\
\hline $26-50 \%$ & $\begin{array}{c}x \\
\text { Diff }=-6 \\
\text { P-value }= \\
0.2337 \\
\text { Family size = } \\
10 \\
\end{array}$ & $\begin{array}{c}\mathrm{x} \\
\text { Diff }=-7 \\
\text { P-value }= \\
0.1519 \\
\text { Family size = } \\
10\end{array}$ & $\begin{array}{c}\mathrm{x} \\
\text { Diff }=-5 \\
\text { P-value }= \\
0.4161 \\
\text { Family size = } \\
10\end{array}$ & $\begin{array}{c}<< \\
\text { Diff }=-22 \\
\text { P-value }= \\
0.0042 \\
\text { Family size }= \\
10\end{array}$ & & $\neq$ & $\neq$ \\
\hline $51-75 \%$ & $\neq$ & $\neq$ & $\neq$ & $\neq$ & $\neq$ & & $\neq$ \\
\hline $\begin{array}{l}\text { Over } \\
75 \%\end{array}$ & $\neq$ & $\neq$ & $\neq$ & $\neq$ & $\neq$ & $\neq$ & \\
\hline
\end{tabular}

$<$ Significantly lower

$>$ Significantly higher

x No significant difference 
‡ A significance test could not be performed because reporting standards were not met, or appropriate standard errors could not be calculated for one or more estimates in the test.

Note: within jurisdiction comparisons on any given year are dependent with an alpha level of 0.05

Table 10: Effect sizes of significant mean score differences between 12 grade enrollment percentages of students enrolled in an ELA dual credit distance learning course, and reading scores.

\begin{tabular}{|c|c|c|}
\hline Frequency 1 & Frequency 2 & Cohen's $d$ \\
\hline $\begin{array}{l}\text { 11-25\% enrollment } \\
(\mathrm{M}=303, \mathrm{SD}=35)\end{array}$ & $\begin{array}{c}0 \% \text { enrollment } \\
(\mathrm{M}=287, \mathrm{SD}=41)\end{array}$ & 0.419 \\
\hline $\begin{array}{c}\text { 11-25\% enrollment } \\
(\mathrm{M}=303, \mathrm{SD}=35)\end{array}$ & $\begin{array}{l}1-5 \% \text { enrollment } \\
(\mathrm{M}=288, \mathrm{SD}=39)\end{array}$ & 0.404 \\
\hline $\begin{array}{l}\text { 11-25\% enrollment } \\
(\mathrm{M}=303, \mathrm{SD}=35)\end{array}$ & $\begin{array}{l}\text { 26-50\% enrollment } \\
(\mathrm{M}=281, \mathrm{SD}=35)\end{array}$ & 0.628 \\
\hline $\begin{array}{l}1-5 \% \text { enrollment } \\
(\mathrm{M}=288, \mathrm{SD}=39)\end{array}$ & $\begin{array}{l}\text { 26-50\% enrollment } \\
(\mathrm{M}=281, \mathrm{SD}=35)\end{array}$ & 0.188 \\
\hline $\begin{array}{c}0 \% \text { enrollment } \\
(\mathrm{M}=287, \mathrm{SD}=41)\end{array}$ & $\begin{array}{l}\text { 26-50\% enrollment } \\
(\mathrm{M}=281, \mathrm{SD}=35)\end{array}$ & 0.157 \\
\hline
\end{tabular}

Identification of effect size, as set by Cohen, are determined by small (0.2), medium (0.5), and large (0.8). Effect size was determined through calculating Cohen's d using enrollment percentages for dual credit earned through distance learning, in relationship to the average scale scores of reading. Comparing 0\% of students to 26-50\% of students taking a dual credit ELA course through distance learning yielded the smallest effect size $(\mathrm{d}=0.157)$. The highest yielding effect size was observed when calculating Cohen's d for 11-25\% and 26-50\% of students taking distance learning dual credit $(\mathrm{d}=0.628)$, considered a medium effect size.

\section{DISCUSSION}

The delivery method of postsecondary credit earned through high school dual enrollment was examined within this study. While dual enrollment has expanded, the instructional delivery options have also diversified to allow more flexibility and opportunity for students. This discussion section will revisit the research questions and review each mode of dual credit instructional delivery, as it pertains to NAEP data. Considering both the access and barriers associated with dual credit enrollment, college readiness factors may be examined more closely and may be associated with the percentage of 12 th grade students enrolled in dual credit, and the specific method of instruction.

\subsection{DUAL CREDIT - HIGH SCHOOL CAMPUS}

\section{Research Question 1}

Examine the impact on NAEP composite reading scores of students who enrolled in an ELA academic course for dual credit taught on a high school campus.

Results within this category of dual credit instructional delivery did not show significant positive or negative effects. The average NAEP reading scale score increased slightly with higher percentages of 12th grade students enrolled in a dual credit ELA course on their high school campus, yet the effect size calculated was small. In this dual credit mode, it is important to note that many instructors who teach college-level courses on a high school campus are in fact high school teachers who have been credentialed with the postsecondary institution (Hebert, 2001). Over the years, dual enrollment options were historically made available to gifted and talented students, and through educational initiatives that promote equity in access, looser restrictions on qualifying for dual credit courses (Howley et al., 2013), along with and creating an alternative for high school adjunct instructors has produced an increase of student participating in this delivery method. In fact, some schools report over $75 \%$ of their 12 th grade students earning dual credit for an ELA course within the NAEP data. 


\subsection{DUAL CREDIT - POSTSECONDARY CAMPUS}

\section{Research Question 2}

Examine the impact on NAEP composite reading scores of students who enrolled in an ELA academic course for dual credit taught on a postsecondary campus.

In this dual credit model, the same faculty member instructs the traditional college course with high school students attending on the postsecondary campus. Experiencing a postsecondary course on the campus provides students with the contextual skills and awareness of "college knowledge" in learning how to be a college student and navigating the postsecondary system in ways such as admission requirements, timelines, placement tests and requirements, and other items (Conley, 2011). Students in this category have an immersive dual credit experience. It does however possess limitations with transportation and access, as stated previously. Results in this category were limited, identifying less students accessing an ELA dual credit course and could not be used for calculations, and no significance in NAEP reading scores for 12th grade students who completed a dual credit course, and those who did not.

\subsection{DUAL CREDIT - DISTANCE LEARNING}

\section{Research Question 3}

Examine the impact on NAEP composite reading scores of students who enrolled in an ELA academic course for dual credit taught through distance learning.

Efforts have been made to increase student access to academically rigorous dual credit courses through online and distance learning opportunities (Mokher, Lee, and Sun, 2019). In reviewing the results pertaining to this research question, the percentage of students enrolled in a dual credit course through distance learning was limited for calculations beyond 50\%. Yet there was one percentage category that yielded a medium effect size when calculating Cohen's d between two student percentage groupings, $11-25 \%$ and $26-50 \%(d=0.628)$, identifying a slight significance of dual credit enrollment and 12th grade NAEP reading scores. In reporting the percentage of students, schools with $11-25 \%$ of their 12th grade students enrolled in distance learning ELA dual credit course experienced higher NAEP reading scores.

\section{CONCLUSIONS}

The delivery method of postsecondary credit earned through high school dual enrollment was examined within this study. While dual enrollment has expanded, the instructional delivery options have also diversified to allow for more flexibility and opportunity for students. Initially, student access to dual credit depended upon traveling to a postsecondary campus. This posed barriers for high schools lacking a college or university in their area, along with transportation, since many high school students are dependent upon a school bus for transportation and unable to drive to a college campus (Roach, Gamez Vargas, and David, 2015). Another barrier to consider is the financial burden of college. State funding allocated for dual enrollment, with all of the requirements set forth by each state, this allows for students to get a head-start and earn postsecondary credit prior to high school graduation. Many states, such as Michigan, have transfer agreements established and the mobility of college credit may be tracked and planned prior to enrollment in the dual enrollment course. This takes some pre-planning and some type of indication of where the student may eventually apply to college or a university. The support systems at the high school level are necessary to assist students with pathway planning and college readiness.

\subsection{COLLEGE READINESS IS VALUABLE}

Students enrolled in advanced courses during high school promote college readiness and may align with domains outlined by Conley (2011). Primarily establishing higher level academic behaviors and contextual skills \& awareness of strategies applicable to postsecondary success. The basic exposure to a college environment benefits student's exposure to both the rigor and associated challenges of college courses (Kanny, 2015). In reviewing 12th grade NAEP data, it is evident within the questionnaires provided to the school administrators that college readiness data is important to identify. 


\subsection{DUAL CREDIT ENROLLMENT IS GROWING}

Within the United States, about three-quarters (76\%) of all high schools reported students enrolled in dual credit courses, specifically with an academic focus such as ELA (Thomas, Marken, Gray, and Lewis, 2013). With more students taking dual credit courses, it has the potential to increase college readiness and decrease the need for remedial courses upon entering college, compared to non-dual enrollment students (Grubb, Scott, and Good, (2017).

\subsection{ONLINE OR DISTANCE EDUCATION REQUIRES MORE ATTENTION}

Very little research is available regarding dual credit through online or distance learning courses. Mokher, Lee and Sun (2019) state within their study that one important component of college and career readiness is to increase student's access to college level courses using online and distance learning technology.

\subsection{INCREASED K-12 \& POSTSECONDARY CONNECTION}

In order to close the gap between secondary and postsecondary education, collaboration promotes a successful transition for students. This may be through instruction specifically, forging connections between high school teachers and college professors. There is the concern of "dumbing down" of dual credit courses when delivered by a high school teacher and the concern regarding lack of qualifications (Zuidema and Eams, 2014) from higher education. Additionally, the transfer of credit and acknowledgement of college level transcripts determined by the postsecondary institution and specific departments, which may be a cost-savings towards student degree progress.

\subsection{IMPLICATIONS}

Many students are enrolling in college level courses such as Advanced Placement (AP) and International Baccalaureate (IB), but the rise of dual credit enrollment continues to grow, as does the modality in which dual credit is offered. Students are electing direct credit options and comparing AP and IB articulated credit through exam scores (Howley et al., 2013). There is another consideration to weigh, and that is dual enrollment saturation through increasing student numbers in an attempt to provide equitable access which may decrease standards or requirements necessary to access dual credit opportunities. Thomas et.al (2013) published national dual credit data, sharing that $63 \%$ of high schools with students enrolled in dual credit courses have established requirements for students to enroll. This leaves about one-third of high schools that are not reporting requirements, with access to dual credit courses potentially determined independently. This is reflected in the 12th grade NAEP data, which suggest more of a bell curve in relationship to the percentage of students taking dual credit ELA and average NAEP scale scores. In each of the instructional delivery methods, distance learning identified the highest average scale scores, demonstrating a need to dive deeper into online dual credit opportunities for students.

\subsection{LIMITATIONS}

This study was limited to the reporting of dual credit courses taken by 12th grade students and reported into three categories of instructional delivery by the school administration, which may bring into question the validity and accuracy. School administrators completing the questionnaire may not have detailed dual credit information that would be associated with academic pathway planning, as would a school counselor. The questionnaire itself was restricted to the identification of a percentage range of students taking dual credit courses at three different locations; additional information regarding course completion or credits earned versus credits attempted was not present. The analysis methods were also limited to the NAEP explorer, not including specific student dual credit information such as prerequisites or requirements set for student enrollment.

\subsection{RECOMMENDATIONS FOR FUTURE RESEARCH}

Future recommendations for research may include researching dual credit course completion and student achievement. In this study the 12th grade NAEP reading assessment was utilized to compare dual credit course 
enrollment and average scale scores. Future research could be conducted to determine a connection between other standardized tests, such as ACT or SAT, and dual credit earned through the instructional delivery of on the high school campus, on a postsecondary campus, and through distance or online learning.

Dual credit and overall college readiness could be further explored, especially with reports of association between students taking dual credit courses and having a positive postsecondary outcome, including more postsecondary credit earned and a higher GPA in college (Zuidema and Eames, 2014). Taking it further, based on the results from the study, isolating dual credit via online or distance learning would be beneficial for both secondary and postsecondary institutions to review. With many K-12 schools shifting to online or remote learning programs, the modality of virtual learning and dual credit options may grow in the future.

It is the desire of educators to provide equitable access for students to programs in which they find success. The prospect of dual credit accessibility and overall dual credit outcomes may shift the definition or intent of rigor associated with dual credit enrollment. Postsecondary faculty members nationally express their agreement in the lack of preparation for the intellectual demands and expectations when students first arrive on campus (Conley, 2011), and the advancement of students through dual credit may propel them into higher level courses they are not yet ready or equipped to take on. Further research in dual credit prerequisites, requirements, and high school support may assist postsecondary institutions in appropriate course placement during freshman year.

\section{SOURCES OF FUNDING}

This research received no specific grant from any funding agency in the public, commercial, or not-for-profit sectors.

\section{CONFLICT OF INTEREST}

The author have declared that no competing interests exist.

\section{ACKNOWLEDGMENT}

None.

\section{REFERENCES}

[1] Adelman, C. (2005). Executive Summary: The Toolbox Revisited--Paths to Degree Completion from High School through College. Journal for Vocational Special Needs Education, 28(1), 23-30. https://files.eric.ed.gov/fulltext/EJ854364.pdf

[2] Adelman, C. (2006). The toolbox revisited: Paths to degree completion from high school through college. US Department of Education. https://files.eric.ed.gov/fulltext/ED490195.pdf

[3] Bond, J., \& Zhang, M. (2017). The Impact of Conversations on Fourth Grade Reading Performance - What NAEP Data Explorer Tells?. European Journal of Educational Research, 6(4), 407-417. doi:10.12973/eujer.6.4.407

[4] CEPI Database. (n.d.). In Center for Education al Performance and Information CEPI. Retrieved from https://www.michigan.gov/cepi/0,4546,7-113-985---,00.html

[5] Conley, D. T. (2011). Redefining College Readiness, Volume 5. Eugene, OR: Educational \ Policy Improvement Center

[6] Focus on NAEP: Sampling. Retrieved from https://www.nationsreportcard.gov/focus_on_naep/files/sampling_infographic.pdf

[7] Grubb, John M, Scott, Pamela H, \& Good, Donald W. (2017). The Answer Is Yes. Community College Review, 45(2), 79-98. https://web-b-ebscohostcom.cmich.idm.oclc.org/ehost/detail/detail?vid=0\&sid=8b0aad86-6ba2-4bf7-978e-9eb0ee47d3ad\%40pdcv-sessmgr04\&bdata=JnNpdGU9ZWhvc3QtbGl2ZQ\%3d\%3d\#AN=121710673\&db=tfh

[8] Hanson, Jana M, Prusha, Todd, \& Iverson, Cort. (2015). Principal, Teacher, and Counselor 
Views of Concurrent Enrollment. New Directions for Community Colleges,2015(169), 71-81. https://onlinelibrary-wiley-com.cmich.idm.oclc.org/doi/full/10.1002/cc.20134

[9] Hébert, L. (2001). A Comparison of Learning Outcomes for Dual-Enrollment Mathematics Students Taught by High School Teachers Versus College Faculty. Community College Review, 29(3), 22-38. https://journals-sagepub-com.cmich.idm.oclc.org/doi/abs/10.1177/009155210102900302

[10] Howley, Aimee, Howley, Marged D, Howley, Craig B, \& Duncan, Tom. (2013). Early College and Dual Enrollment Challenges. Journal of Advanced Academics, 24(2), 77-107. https://journals-sagepubcom.cmich.idm.oclc.org/doi/full/10.1177/1932202X13476289

[11] Hughes, Katherine L, \& Edwards, Linsey. (2012). Teaching and learning in the dual enrollment classroom. New Directions for Higher Education, 2012(158), 29-37. https://onlinelibrary-wileycom.cmich.idm.oclc.org/doi/abs/10.1002/he.20012

[12] Kanny, M. A. (2015). Dual Enrollment Participation From the Student Perspective. New

Directions for Community Colleges, 2015(169), 59-70. https://onlinelibrary-wileycom.cmich.idm.oclc.org/doi/full/10.1002/cc.20133

[13] Martinez, Melissa A, Valle, Fernando, Cortez, Laura J, Ponjuan, Luis, \& Sáenz, Victor B.

(2018). Context Is Key: School Leaders' Approaches in Creating and Maintaining Dual Enrollment Opportunities in South Texas. Leadership and Policy in Schools,17(4), 516-540. https://web-b-ebscohostcom.cmich.idm.oclc.org/ehost/pdfviewer/pdfviewer?vid=1\&sid=defa4e4b-dde7-4318-bf2757c7243c0d2e\%40pdc-v-sessmgr05

[14] Mokher, Christine G, Lee, Steve, \& Sun, Christopher. (2019). Evaluating Innovations for Improving College and Career Readiness in Rural Schools. Research in the Schools, 26(1), 48-63. https://search-proquestcom.cmich.idm.oclc.org/docview/2352142912?accountid=10181\&rfr_id=info\%3Axri\%2Fsid\%3Aprimo

[15] National Center for Educational Statistics (NCES).(2018a). An overview of NAEP. Retrieved fromhttps://nces.ed.gov/nationsreportcard/subject/about/pdf/NAEP_Overview_Brochure_2018.pdf

[16] NCES (2020). History and Innovation. Retrieved from https://nces.ed.gov/nationsreportcard/about/timeline.aspx

[17] NCES (2018b). Frequently Asked Questions. Retrieved from https://nces.ed.gov/nationsreportcard/about/faqs.aspx

[18] NCES (2016). The Nation's Report Card: 2015 Reading Grade 12. Retrieved from https://www.nationsreportcard.gov/reading_math_g12_2015/\#reading

[19] Phelps, L., \& Chan, H. (2016). Optimizing Technical Education Pathways: Does Dual-Credit Course Completion Predict Students' College and Labor Market Success? Journal of Career and Technical Education, 31(1), 61-84

[20] Pupil Accounting Manual (2019). In State of Michigan - Department of Education. Retrieved from 20_Pupil_Accounting_Manual_672533_7.pdf\#page=84

[21] Reading, Mathematics, and Science School Questionnaire - 2015 Grade 12. (2015). In National Assessment of $\quad$ Educational $\quad$ Retrieved from https://nces.ed.gov/nationsreportcard/subject/about/pdf/bgq/school-sdlep/2015_bq_school_g12_rms.pdf

[22] Roach, Rick, Gamez Vargas, Juanita, \& David, Kevin M. (2015). Eliminating Barriers to Dual Enrollment in Oklahoma. New Directions for Community Colleges, 2015(169), 31-38. https://onlinelibrarywiley-com.cmich.idm.oclc.org/doi/epdf/10.1002/cc.20130

[23] Thomas, N., Marken, S., Gray, L., \& Lewis, L. (2013). Dual credit and exam-based courses in U.S. public high schools: 2010-11. Washington, DC: National Center for Education Statistics. Retrieved February 10, 2014 from https://nces.ed.gov/pubs2013/2013001.pdf

[24] Zuidema, Daniel R, \& Eames, Kevin J. (2014). Comparison of High School Dual-Enrollment and Traditional First-Term General/Organic/Biochemistry College Chemistry Class Outcomes. Journal of Chemical Education, 91(12), 2058-2063. 